\title{
ヘルシンキ工科大学滞在記
}

\section{Study Abroad at Helsinki University of Technology}

\author{
by
}

\author{
Hiroshi KawaKami ${ }^{*}$
}

\section{1 は じめに}

2005 年 9 月から一年間，筆者が勤務する大阪市立大 学の在外研究制度により，フィンランド共和国の Teknillinen Korkeakoulu（ヘルシンキ工科大学，通称 TKK）に客員研究員として研究滞在する機会を得ました. フィンランドは人口およそ 520 万人, 面積 34 万平方キ 口, 北緯 $60^{\circ} \sim 70^{\circ}$ に位置し国土の $1 / 4$ は北極圈に位置 します.フィンランド語とスウェーデン語が公用語です. スウェーデン語だけで講義が行われる大学もあります。

日本とは文化や環境が異なるフィンランドに滞在中， フィンランドの大学生活や研究事情について筆者が見聞 きしたことをご紹介します。

\section{2 教 育 事 情}

フィンランドでは 7 歳から 9 年間の基礎教育を受けた 後, $3 \sim 4$ 年の高等学校もしくは $2 \sim 5$ 年の職業専門学 校に進学します。人口の $60 \%$ は中等教育を修了します. 中等教育終了後, 多くの人が大学や高等職業専門学校 (Polytech) に進学し 13\% が学士号もしくは同等の学位を 取得します。一部の高等職業専門学校を除き学校は国公 立で学費はいりません，親しくしてくれた学生が話して くれたところによると学校での進路指導は特になく, 基 礎教育修了後の進路については本人が決めるのが当たり 前だそうです。

\section{Teknillinen Korkeakoulu}

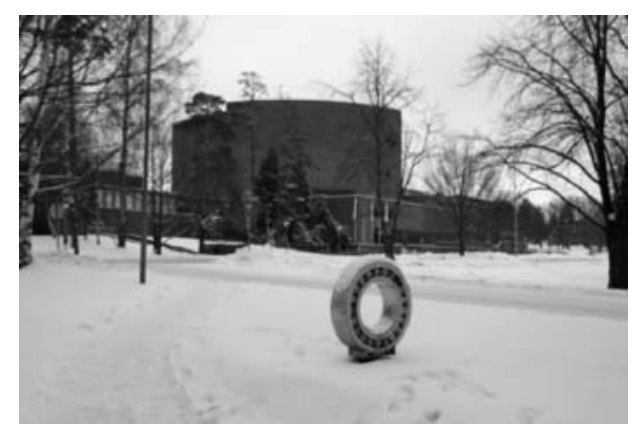

困 1 TKK メインビル (建築家 Alto 夫妻による設計)

1849 年に設立された技術学校が 1908 年にヘルシンキ 工科大学となりました。TKK はフィンランドにある 20 の大学の中で 2 番目に古く, 理工系では最も古い大学で
す。創設時には首都 Helsinki にありましたが 1966 年に Helsinki 郊外のハイテク都市 Otaniemi に移りました。こ こは Otaniemi SciencePark と Innopoli Technology Center からなる理科系教育と技術開発の拠点であり, 携帯電話端 末で有名な Nokia 本社も Otaniemi にあります。 Otaniemi はAward of Excellence for Innovative Regions 賞を EU より 2 度受賞しています。

TKK と同じ敷地内にVTT Tuotteet ja tuotanto（フィ ンランド国立技術研究所）があり, 多くの研究プロジェ クトに TKK とともに参加しています.TKKがどちらか というと基礎研究, VTT が応用研究を行う傾向にありま す.VTTは研究所ですが学位授与機構でもあり, 研究室 のトップは Professor です.

TKK では学部・博士前期課程一貫教育が行われており およそ 15000 人の学生が修士号をめざし研究しています. 学生によると, 修士号取得まで平均 9 年かかるそうです. 毎年 1500 人が入学し 1000 人が修士号を, 150 人が博士 をそれぞれ取得するそうです。これらの学生を教授 250 人を含む教職員およそ 3000 人が指導しています.

大学での単位習得方法も日本のそれと異なります。学 生が登録科目の担当教官をセメスターの始めに尋ねると 教官が教科書を指定します。学生は指定された教科書に 沿って独学で勉強し, 学生本人が十分理解したと思った 時点でふたたび教官を尋ねます。すると教官が試験問題 を作成し，扎よそ 1 週間後に試験が行われます。筆者が 所属した研究室の休憩室で学生が一人で試験問題に取り 組んでいることも多々ありました。試験を受けるまでの 期間は登録後 1 年半以内であればよいそうです。また TKK では学外から講師を招いたセミナーが頻繁に行われ ます。単位を取得するための条件は教官より指定された 6 回ほどのセミナーに出席しレポートを受理されること と先に述べた試験に合格することです。 日本の大学で行 われているような講義を TKK の教員が行うことはあり ません。

TKK での勤務時間は 8：00 から $15 ： 45$ です。その間， 昼食 (1 時間) とは別に午後 1 時から 30 分ほどは有名な コーヒーブレイクがあり, 午後 3 時を過ぎると人々は帰り 始めます. 午後 5 時以降は建物の中に人気がありません. TKK 入学と同時に学生は研究室に所属し, 給与が支払わ

$\dagger \quad$ 原稿受理 平成 18 年 12 月 21 日 Received Dec. 21, 2006 @ 2007 The Society of Materials Science, Japan

* 正 会員 大阪市立大学大学院工学研究科機械物理系専攻 =558-8585 大阪市住吉区, Dept. Mech. Phys. Eng., Osaka City Univ., Sumiyoshi, Osaka, 558-8585 
れます。上記の勤務時間は学生にも適用され 1 年間の有 給休㗇日数も決められています，有給休㗇は 14 日/年 ですがこれは教授との交渉により増やすこともできるそ うです。

筆者は機械工学科（14 研究室）に属する機械材料研 究室に所属しました。この研究室は Hänninen 教授を始 め助教授 1 名, 研究者 25 名 (Senior Research Scientist （博士号を有し研究実績のある者）4名, Research Scientis （博士号取得直後の者や博士号を持たない者，学生） 21 名），技官 5 名，事務員 1 名の総勢 33 名が所属する大き な研究室でした。教授・助教授は研究室全体を統括し, Senior Research Scientist が各研究テーマを統括します. Research Scientist は Senior Research Scientistによる指 導者の下, 個々の研究テーマに取り組みます。機械材料 研究室では金属の熱疲労, 残留応力測定, 高強度オース テナイト鋼の加工性，超塑性加工の実用化，摩擦圧接に よる異種材料接合について実験・研究を抗こなっていま した。筆者はこの研究室で始まったばかりの二酸化チタ ン光触媒に関するプロジェクト研究に参加しました。

\section{銅およびその合金}

\section{4 研 究の 特 徵}

フィンランドでは銅ぶきの屋根や雨樋が多く使われて います。これはフィンランド北部で銅が採掘されるため であり，今後銅合金の使用範囲を拡張していく事を目的 とした研究が盛んに行われています。機械材料研究室で も銅合金の熱疲労に関する研究が行われていました。

\section{製紙技術}

製紙産業はフィンランドの三大主要輸出産業の一つで す。笛のため製紙技術に関する研究も盛んに行われてい ます，TKKには製紙技術に関する研究開発に主眼をおい た学科 Department of Forest Products and Technology があり，これはTKKの中でも大きな学科です。機械材 料研究室ではパルプ䀣濁液による金属の摩耗と腐食につ いて研究を打こなっていました。摩耗や腐食により製紙 機械が損傷を受けるだけでなく，摩耗による粒子や腐食 によるイオンがパルプに混入し製品の質が低下します。 これらの損害を防ぐのが目的です。

\section{原子力発電関係}

フィンランドの大地は平坦であり最も高い山でも海抜 $500 \mathrm{~m}$ 程です。また“森と湖の国”と称されるように水 は豊富にありますが，一年の大半は凍結しているため水 力発電は行えません。現在は火力発電が主ですが今後は 原子力発電に切り替えていく予定で, 複数の原子力発電 施設が今後建設されるそうです。それらの原子力発電施 設で銅合金を多用したいそうです。また原子力発電施設 よりでる放射性廃棄物の保存タンクへの銅合金の使用を 目指した研究も行われています.

\section{大学発ベンチャー起業と産学連携}

大学発のベンチャー起業が盛んに行われています。ただ し TKK に所属する者が起業するには大学を離れなくては なりません，現に筆者と入れ替わりで研究室の Research
Scientist 2 名（内 1 名は昨年度の最も優秀な学生として TKKから表彰された。）が共同で起業するためにTKK を 退学しました。

フィンランドではよほど大きな企業でない限り社内に 実験・研究施設をもたないそうです。そのため企業は実 験や研究を大学や国立技術研究所に依頼します。研究室 の収入の大半がそのような企業からの受託研究費です. Senior Research Scientist は複数の受託研究に携わっ ており, Senior Research Scientist本人とその下で働く Research Scientistの給与は受託研究費でまかなわれ ます. 受託研究の期間は 1 年以下であることが多いそう です.

\section{研究とは無関係ですが}

TKK の敷地内に火力発電施設があり TKK およびVTT で消費される電力をまかなっています。またこの発電施設 から敷地内の建物に温水が供給され暖房に使われていま す。学外でも住宅地の近くに炏発電施設が在り周辺の 建物に電力と熱源を供給しています。寒い冬が長いフィ ンランドではこのようなコジェネレーションが発達して います。

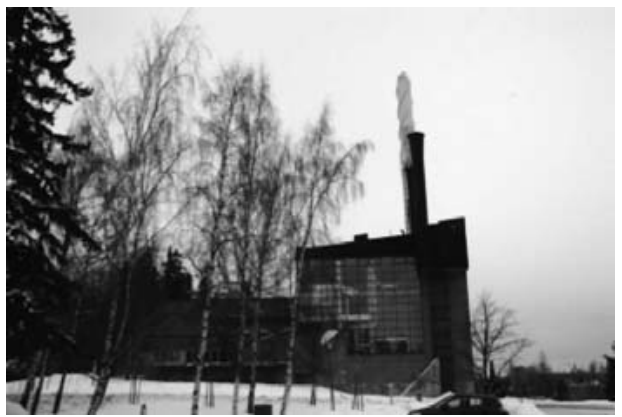

図 2 大学構内にある火力発電所。その大部分はガラ ス張りで中の配管を見ることができる

\section{5 最後に}

筆者の気に入ったフィンランドの言葉の一つに “middle weekend”があります．残念ながらフィンランド語でな んというのか忘れてしまいました。フフィンンドの人々 は水曜日には “今日は middle weekend” と言いながら 普段よりも早く，人によっては昼食を済ませると，先れ ぞ机家路に付きます。

（上記の内容は筆者滞在中のものです，フィンランドで は研究者の大学ばなれが進んでいるらしく, TKKでも教 育・研究制度が改変中だそうです。）

フィンランドで研究生活を送るという素晴らしい機会 を与えていただいた大阪市立大学に感謝の意を表します。 筆者の留守中 研究室を運営管理していただいた佐藤教授 を始め, 工学研究科機械物理系専攻のみなさまに感謝の 意を表します。またフィンランド語をまったく解せず 研究内容についても無学であった筆者を受け入れてくれ た Hänninen 教授，乞してHänninen 教授を紹介してくだ さった菊地靖志大阪大学名誉教授に感謝の意を表します. 